Jurnal Geografi, Edukasi dan Lingkungan (JGEL) Vol. 3, No. 1, Januari 2019:45-54

P-ISSN: 2579-8499; E-ISSN: 2579-8510

DOI: https://doi.org/10.29405/jgel.v3i1.2992

Website: http://journal.uhamka.ac.id/index.php/jgel

\title{
Peremajaan Permukiman Kumuh Dengan Penerapan Konsep Ecovillage
}

\author{
Wardana Wibawa ${ }^{1}$, dan Alwin ${ }^{1}$ \\ ${ }^{1}$ Sekolah Pascasarjana Universitas Pendidikan Indonesia \\ *E-mail: wardanaunibba@ gmail.com \\ Received: 09102018 / Accepted: 11122018 / Published online: 17012019
}

\begin{abstract}
ABSTRAK
Permukiman kumuh merupakan salah satu masalah yang dapat timbul dalam suatu kota atau kabupaten. Desa Bojongsoang Kabupaten Bandung menjadi salah satu wilayah yang menghadapi masalah pertumbuhan permukiman kumuh. Faktor penyebab kumuhnya permukiman di Desa Bojongsoang yakni akibat aktifitas yang terlalu berlebihan, sehingga menyebabkan lingkungan hunian menjadi tidak sehat dan tidak nyaman untuk ditinggali. Adanya permasalah ini masyarakat berinisiatif melakukan program ecovillage sebagai solusi untuk mengatasi permasalahan. Tujuan penelitian adalah menerapkan konsep ecovillage di Desa Bojongsoang Kabupaten Bandung. Konsep ecovillage adalah konsep penataan permukiman yang menggunakan prinsip berkelanjutan dengan mengedepankan aspek lingkungan dan berintegrasi dengan dimensi sosial, ekonomi, dan budaya. Metode penelitian yang digunakan adalah metode penelitian kualitatif dengan pendekatan studi literatur, studi banding, dan observasi objek. Analisis dalam penelitian ini dilakukan dengan cara melakukan perbandingan antara hasil observasi objek dengan studi literatur. Hasil yang dicapai dalam penelitian ini membuktikan bahwa untuk mengatur kawasan permukiman kumuh dapat dilakukan dengan cara peremajaan permukiman, melalui penerapan lima konsep karakteristik ecovillage, sehingga diharapkan dapat menghasilkan permukiman yang bersifat berkelanjutan dan ekologis.
\end{abstract}

Kata Kunci: Peremajaan, Permukiman Kumuh, Ecovillage

\begin{abstract}
Slum settlement is one of the problems that can occur in cities or districts. Bojongsoang Village, Bandung Regency is one of the areas that intersects with slums. The population growth rate in cities or regencies, the number of poor and low-income people, and the rate of urbanization can trigger the proliferation of slums. The factors that caused the slum of settlements in Bojongsoang Village were due to over-activity, which caused the housing to become unhealthy and uncomfortable to live in. With this problem the community took the initiative to conduct the ecovillage program as a solution to overcome the problem. The formulation of the problem used is "How is the application of the concept of ecovillage in Bandung Regency?". The ecovillage concept is a settlement arrangement concept that uses sustainable principles by prioritizing environmental aspects and integrating social, economic and cultural dimensions. In these locations there are settlement patterns that are not yet clear, so that it needs to be done rejuvenation or redevelopment of slums to improve the quality of slums into
\end{abstract}


Jurnal Geografi, Edukasi dan Lingkungan (JGEL) Vol. 3, No. 1, Januari 2019:45-54

P-ISSN: 2579-8499; E-ISSN: 2579-8510

DOI: https://doi.org/10.29405/jgel.v3i1.2992

Website: http://journal.uhamka.ac.id/index.php/jgel

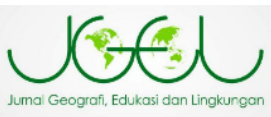

developing settlements. The research method, which is a qualitative research method with a literature study approach, milkfish studies, and objects. The analysis in this study was conducted by comparing the measurements with the study of literature. The results in this study prove that to regulate settlements can be done by means of settlements, through the implementation of ecovillage concepts, making it possible to produce sustainable and ecological settlements.

Keywords: Rejuvenation, Slums, Ecovillage

\section{PENDAHULUAN}

Lingkungan hidup di Indonesia yang dikaruniakan oleh Tuhan Yang Maha Esa kepada Bangsa dan Rakyat Indonesia, merupakan rahmat dari padaNya dan wajib dikembangkan dan dilestarikan kemampuannya agar dapat menjadi sumber dan penunjang hidup bagi Bangsa dan Rakyat Indonesia serta makhluk lainnya. Hal ini demi kelangsungan dan peningkatan kualitas hidup itu sendiri. Menurut Undangundang No. 13 Tahun 1997, lingkungan hidup didefinisikan sebagai kesatuan ruang dengan semua benda, daya, keadaan, dan makhluk hidup, termasuk manusia dan perilakunya, yang mempengaruhi perikehidupan dan kesejahtraan manusia serta makhluk hidup lain. Apabila kita kaji berdasarkan apa yang terdapat dalam UU No. 13 di atas nyatanya pengertian lingkungan hidup sangatlah luas, tidak hanya apa yang kita lihat tetapi semua aspek dalam lingkungan tersebut berbanding lurus dengan tingkat kesejahtraan manusia atau makhluk hidup.

Menurut Sumaatmadja (1988), "kondisi di sekitar makhluk hidup, yang berpengaruh terhadap pertumbuhan dan karakternya". Artinya lingkungan hidup mempunyai peranan yang sangatlah penting sebagai media bagi makhluk hidup. Akan tetapi, perkembangan pembangunan, teknologi, industrialisasi, dan pertumbuhan penduduk yang semakin pesat, semakin memperbesar risiko kerusakan lingkungan hidup. Hal ini sampai kepada titik dimana isu lingkungan hidup menjadi suatu permasalahan yang dianggap serius. Salah satunya adalah berdampak bagi sehat atau tidaknya suatu permukiman. Permukiman yang tingkat kepedulian terhadap lingkunganya tinggi akan mendapatkan semakin sehat suatu lingkungan tersebut, begitu pula sebaliknya apabila tingkat kepeduliannya semakin rendah maka pemukiman tersebut akan semakin kumuh. Permukiman kumuh merupakan salah satu masalah yang dapat timbul dalam suatu kota atau kabupaten. Kabupaten Bandung adalah salah satu daerah yang menghadapi masalah pertumbuhan permukiman kumuh. Laju pertambahan penduduk di suatu daerah, tingginya jumlah warga miskin dan berpenghasilan rendah, serta laju urbanisasi dapat menjadi pemicu menjamurnya permukiman kumuh (slum). Salah satu contoh permukiman kumuh penduduk yaitu di Desa Bojongsiang, Kabupaten Bandung.

Kumuhnya permukiman di Desa Bojong Soang akibat aktifitas yang terlalu berlebihan, sehingga menyebabkan lingkungan hunian menjadi tidak sehat dan tidak nyaman untuk ditinggali. Kondisi lokasi penelitian pada tahun 1017 telah dipenuhi oleh permukiman kumuh, pada lokasi tersebut terdapat tata kelola yang begitu teratur, sehingga perlu dilakukan peremajaan atau redevelopment terhadap permukiman kumuh tersebut. Hal ini dilakukan untuk meningkatkan kualitas permukiman kumuh tersebut 
Jurnal Geografi, Edukasi dan Lingkungan (JGEL) Vol. 3, No. 1, Januari 2019:45-54

P-ISSN: 2579-8499; E-ISSN: 2579-8510

DOI: https://doi.org/10.29405/jgel.v3i1.2992

Website: http://journal.uhamka.ac.id/index.php/jgel

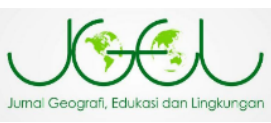

menjadi permukiman yang berkembang. Permukiman kumuh yang cenderung meluas ini perlu untuk segera ditangani. Melalui penelitian ini, diharapkan dapat terwujud suatu permukiman yang layak huni dalam suatu lingkungan yang sehat, yakni akan direncanakan sebagai model permukiman yang ekologis atau dikenal dengan istilah ecovillage, dengan merencanakan permukiman kumuh ini sebagai permukiman berbasis ekologis.

Berdasarkan latar belakang diatas maka perumusan masalah yang diambil pada penelitian ini adalah "Bagaimana menerapkan konsep ecovillage di Kabupaten Bandung?". Adapun tujuan dari peremajaan permukiman kumuh di Kabupaten Bandung adalah sebagai upaya untuk mengurangi tata kelola ruang pedesaan yang salah, serta menerapkan 5 karakteristik ecovillage di Kabupaten Bandung dan mengoptimalkan potensi di Desa Bojongsoang untuk menerapkan ecovillage di Babupaten Bandung.

\section{METODE PENELITIAN}

Metode penelitian yang dipergunakan adalah kualitatif dengan pendekatan studi literatur, studi banding dan observasi obyek pemukiman. Data dan sumber data yang diambil adalah Data primer merupakan data yang diambil langsung di lapangan meliputi foto pemukiman dan kegiatan masyarakat. Observasi dilakukan secara observasi partisipatif. Data sekundernya didapat dari metode kepustakaan, peraturan perundang-undangan, penelitian terdahulu, ataupun berupa artikel-artikel, sehingga hasil yang didapatkan bias dikaji dan memberikan solusi penanganan.

\section{HASIL DAN PEMBAHASAN}

Eco-village atau desa berbudaya lingkungan bertujuan membuat masyarakat mampu mengelola lingkungannya sesuai dengan kaidah keberlanjutan meliputi konservasi, pemanfaatan dan pemulihan lingkungan. Adapun peranan Eco-village disini adalah sebagai Fasilitator masyarakat untuk mengidentifikasi, mengkaji serta memecahkan berbagai persoalan yang dirasa mengganggu kesejahtraan masyarakat. Kegiatan pengembangan Desa atau Kampung Berbudaya Lingkungsn ini dimaksudkan agar masyarakat mengetahui, memahami dan menguasai persoalan, potensi dan kebutuhan kawasan sekitar. Hal ini diharapkan masyarakat dapat mencari alternativ pemecahan masalah yang relativ mudah dilaksanakan secara swadaya.

Berbagai masalah pembangunan seperti kemiskinan, pengangguran, urbanisasi dan masalah kependudukan, mengarahkan berbagai pihak untuk melakukan percepatan dan pemerataan pembangunan. Salah satunya dengan menurunkan ketimpangan kemajuan antar wilayah dan antara perkotaan dan perdesaan. Fakta menunjukkan bahwa masih banyak potensi alam yang umumnya terdapat di wilayah perdesaan, belum tergali dan termanfaatkan, demikian halnya masih banyak industri primer yang belum mendapat sentuhan nilai tambah ekonomi.

Hasil penelitian menunjukkan bahwa peningkatan nilai tambah produk pertanian primer (second cropp) di beberapa negara dipercaya berhasil mengurangi kemiskinan, terutama kemiskinan di pedesaan dan di sektor pertanian. Sementara itu, di sisi lain banyak hasil kajian dan penelitian mengenai teknologi terapan dan pemberdayaan ekonomi masyarakat yang belum diimplementasikan. Kenyataan tersebut mendorong semua pihak untuk menggerakkan pembangunanpembangunan perdesaan dan pertanian. 
Jurnal Geografi, Edukasi dan Lingkungan (JGEL) Vol. 3, No. 1, Januari 2019:45-54

P-ISSN: 2579-8499; E-ISSN: 2579-8510

DOI: https://doi.org/10.29405/jgel.v3i1.2992

Website: http://journal.uhamka.ac.id/index.php/jgel

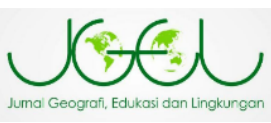

Terlebih lagi fakta menunjukkan bahwa pertanian merupakan sektor ekonomi yang mampu bertahan di era krisis ekonomi. Sebagai salah satu upaya ke arah tersebut adalah melalui rancang bangun kawasan dan infrastruktur pedesaan yang dapat menciptakan suatu kawasan yang ideal, baik untuk kegiatan ekonomi produksi maupun sebagai kawasanpemukiman.

Ecovillage merupakan pembangunan kawasan perdesaan yang mempertimbangkan pencapaian kualitas individu, keluarga, masyarakat serta kualitas lingkungan alam yang berkelanjutan. Hal ini diharapkan akan terjadi arus balik dari kota ke desa yang dapat mengurangi masalah kependudukan, masalah urbanisasi, masalah energi, serta masalah sosial perkotaan yang makin kompleks.

Secara umum di Desa Bojongsoang kondisi kawasan perdesaan masih tetap dicirikan oleh masih besarnya jumlah penduduk miskin, terbatasnya alternatif lapangan kerja, dan rendahnya tingkat produktivitas tenaga kerja perdesaan. Kondisi tersebut terkait berbagai kendala yang melekat seperti: 1) rendahnya tingkat penguasaan lahan pertanian oleh rumah tangga petani dan tingginya ketergantungan pada kegiatan budidaya pertanian (on farm), 2) lemahnya keterkaitan kegiatan ekonomi antara sektor pertanian dengan sektor industri pengolahan dan jasa penunjang serta keterkaitan antara kawasan perdesaan dan kawasan perkotaan, 3) rendahnya tingkat pendidikan dan keterampilan masyarakat perdesaan, 4) rendahnya akses masyarakat kepada sumber permodalan dan sumber daya ekonomi produktif lainnya, dan 5) masih terbatas serta belum meratanya tingkat pelayanan prasarana dan sarana dasar bagi masyarakat.

Berbagai dokumentasi dan laporan melaporkan ketimpangan dan

ketidakadilan pembangunan kawasan perdesaan. Padahal kawasan perdesaan merupakan kawasan yang memiliki fungsi sebagai tempat pemukiman, pelayanan jasa pemerintahan, pelayanan sosial, dan kegiatan ekonomi. Kegiatan ekonomi utama di kawasan perdesaan adalah pertanian, termasuk pengelolaan sumber daya alam. Hal ini antara lain tercermin dari data ketenagakerjaan yang menunjukkan bahwa dari seluruh tenaga kerja yang bekerja di perdesaan pada tahun 1006 (57,3 juta orang atau 60,0 persen dari total tenaga kerja nasional), sebanyak 37,6 juta $(65,7$ persen $)$ diantaranya bekerja di sektor pertanian (Sakernas, 1006).

Pengembangan perdesaan hendaknya bertumpu pada potensi desa yaitu kemampuan atau daya atau kekuatan yang memungkinan dikembangkan dalam wilayah otonomi desa. Oleh karenanya, menjadi tantangan pembangunan nasional agar memiliki strategi utama pembangunan desa sebagai pusat pertumbuhan. Demikian halnya strategi pembangunan perdesaan yang memperhatikan modal sosial yang ditunjukkan oleh tingkat integrasi social, kinerja institusi sosial, dan adanya kepercayaan serta kemampuan penduduk memecahkan masalah sosial. Kebijakan dan program pembangunan hendaknya mengembangkan pendekatan yang berimbang dan saling mendukung, serta kesaling ketergantungan seluruh aspek kehidupan antara kawasan perkotaan dan perdesaan, atau yang dikenal sebagai rural-urban linkage development approach.

\section{Ecovillage sebagai Solusi Pembangunan Perdesaan}

Pembangunan perdesaan hendaknya mengacu kepada konsep pembangunan wilayah yang selain memperhatikan semua fasilitas pemenuhan kebutuhan 
Jurnal Geografi, Edukasi dan Lingkungan (JGEL) Vol. 3, No. 1, Januari 2019:45-54

P-ISSN: 2579-8499; E-ISSN: 2579-8510

DOI: https://doi.org/10.29405/jgel.v3i1.2992

Website: http://journal.uhamka.ac.id/index.php/jgel

hidup penduduk yang berkualitas, juga memenuhi pembangunan sarana infrastruktur pertanian dan perdesaan yang memadai. Hal tersebut menjadi penting, karena dapat meningkatkan akses dan peluang bekerja, berproduktivitas, dan membuat penduduk nyaman untuk tinggal dan bekerja pada sektor pertanian dan industri di perdesaan. Penataan kawasan dan pemukiman hendaknya dilakukan dengan menekankan efisiensi pengelolaan tata ruang dan lingkungan serta potensi sumberdaya lokal lainnya.

Sementara itu, pengelolaan produksi dan penggunaan energi mengacu kepada konsep ketahanan pangan untuk menjamin pemenuhan kebutuhan pokok pangan dan gizi penduduk. Selain itu, pengelolaan tata ruang dilakukan untuk mengatur kenyamanan penduduk (individu, keluarga, dan masyarakat) dengan memperhatikan aspek densitas, personal, privasi, dan teritorial. Sekaligus menjamin pemenuhan kebutuhan pokok lainnya, seperti akses terhadap pelayanan kesehatan dan kesempatan pendidikan.

Aspek lainnya dalam ecovillage adalah pemanfaatan dan penerapan teknologi untuk memecahkan masalah pemenuhan kebutuhan masyarakat yang mendesak seperti kecukupan energi, air bersih, sarana komunikasi, akses terhadap pasar, akses terhadap pengembangan IPTEKS, serta peningkatan kualitas dan nilai tambah komoditas ekspor dan komoditas konsumsi dalam negeri. Adanya pengembangan teknologi tersebut di tingkat masyarakat akan meningkatkan kesiapan Indonesia menghadapi persaingan global, serta mendukung pemenuhan salah satu target Sustainabel Development Goals (SDGs).

Pembangunan pedesaan yang dicirikan oleh pemanfaatan kawasan berdasarkan potensi yang tersedia, dengan pengelolaan yang memperhatikan keberlanjutan sumberdaya pedesaan dikenal dengan pengembangan ecovillage. Ecovilage merupakan satu kesatuan antara pemukiman dan segenap unit usaha yang dikembangkan masyarakat, dilengkapi dengan prasarana dan sarana yang cukup untuk kehidupan sehari-hari dan untuk berusaha.

Pengelolaan usaha dan antar usaha dilakukan secara terpadu, sehingga sumberdaya kampung digunakan secara efesien. Usaha yang dikembangkan dicirikan oleh pemanenan energi matahari, aliran energi yang efisien dianatara usaha pertanian dan non pertanian yang dikembangkan, meminimumkan input eksternal dalam pertanian dengan memanfaatkan penggunaan limbah biomassa untuk pertanian, dan praktek pertanian yang mengkonservasi tanah dan air. Pemukiman dilengkapi dengan sarana dan prasarana umum dan sosial yang cukup, ditata dengan menonjolkan aspek kesehatan lingkungan, kenyamanan, dan keindahan

Kegiatan pengembangan Ecovillage di Kabupaten Bandung ini mulai dilaksanakan pada tahun 2015 pada 65 Desa di 9 Kecamatan, 8 Kecamatan Kabupaten Bandung diantaranya Pasirjambu, Pangalengan, Cimaung, Bojongsoang, Baleendah Ciparay, Solokanjeruk dan Cicalengka. Program Eco-Village di kabupaten Bandung menitikberatkan terhadap penyelesaian permasalahan sampah yang berada di DAS Citarum berikut pula anak-anak sungai yang bermuara ke DAS Citarum. Hal didasarkan atas kondisi DAS Citarum saat ini sudah sangatlah kritis, terbukti dari hasil pengolahan dengan Metode Storet di seluruh lokasi pemantauan terkategori cemar berat (D). Limbah dan sampah menjadi faktor utama yang mengakibatkan ketercemaran. Berdasarkan hal tersebut, program EcoVillage ini sangatlah gencar di galakan di 
Jurnal Geografi, Edukasi dan Lingkungan (JGEL) Vol. 3, No. 1, Januari 2019:45-54

P-ISSN: 2579-8499; E-ISSN: 2579-8510

DOI: https://doi.org/10.29405/jgel.v3i1.2992

Website: http://journal.uhamka.ac.id/index.php/jgel

Kabupaten Bandung guna mengatasi permasalahan-permasalahan yang berkaitan dengan lingkungan, dan masalah-masalah yang timbul karena faktor lingkungan atau alam. Berdasarkan pertimbangan peranan DAS Citarum sebagai sumber kehidupan bagi seluruh masyarakat yang berada di Jawa Barat dan khususnya di Kabupaten Bandung. Salah satu titik yang menjadi sasaran atau target pembenahan di DAS Citarum adalah penataan pada sungai mati, dan diharapkan program Eco-village ini dapat mengatasi atau sedikitnya memberikan kontribusi positif dalam penyelesaian permasalahan di DAS Citarum.

Kegiatan mewujudkan pelestarian lingkungan, maka dibutuhkan peran serta semua pihak, baik pemerintah, steakholder yang bergerak dalam bidang lingkungan dan masyarakat. Hal ini untuk melaksanakan analisis yang terkait dengan penerapan konsep ecovillage, menggunakan komponen 5 karakteristik dari ecovillage yang ditulis oleh (Jonathan Dawson, 2007), untuk memudahkan mengenali karakter ecovillage, sebagai berikut:

1. Proyek ecovillage tidak dimulai oleh pemerintah dalam atau perusahaan, tetapi berasal dari inisiatif partisipasi masyarakatnya.

Kondisi eksisting permukiman, akan dianalisa kondisi rumah yang ada didalam tapak. Besaran rumah yang ada di Desa Bojongsoang rata-rata berukuran $<10 \mathrm{~m}^{2}$ dengan jumlah anggota keluarga 3-6 orang. Hal tersebut mengakibatkan pembagian ruang sulit untuk dilakukan dan menjadi tidak teratur. Material bangunan rumah yang digunakan oleh sebagian warga masih sangat sederhana dan non permanen. Foto - foto keadaan rumah di Desa Bojongsoang (Gambar 1).

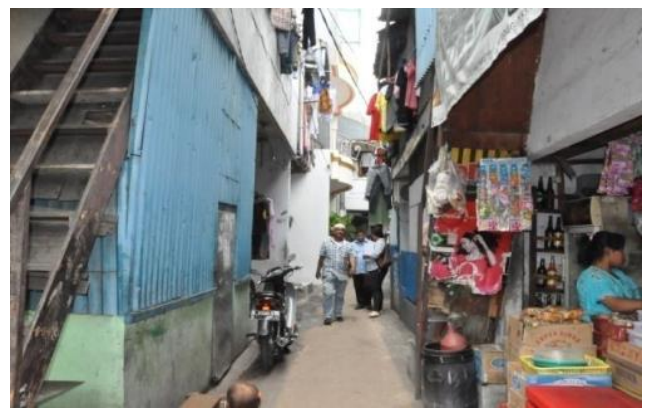

Gambar 1: Kondisi Eksisting Permukiman

Respon desain berupa tempat tinggal yang nyaman secara thermal. Bangunan rumah akan dibuat menjadi bangunan permanen yang layak huni, dan disediakan ventilasi buatan dengan sistem cross ventilation. Kondisi ini dilakukan agar sirkulasi pencahayaan dan penghawaan dapat masuk ke hunian secara maksimal, dan adanya pembagian pola ruang-ruang di dalam hunian agar menjadi ruang yang teratur.

Jalan lingkungan eksisting permukiman, akan dianalisa pola jalan lingkungan yang terbentuk. Jalan tersebut merupakan jalan-jalan gang rumah yang kurang terakses dengan jalan lain atau buntu. Foto-foto kondisi jalan lingkungan di Kabupaten Bandung (Gambar 2).

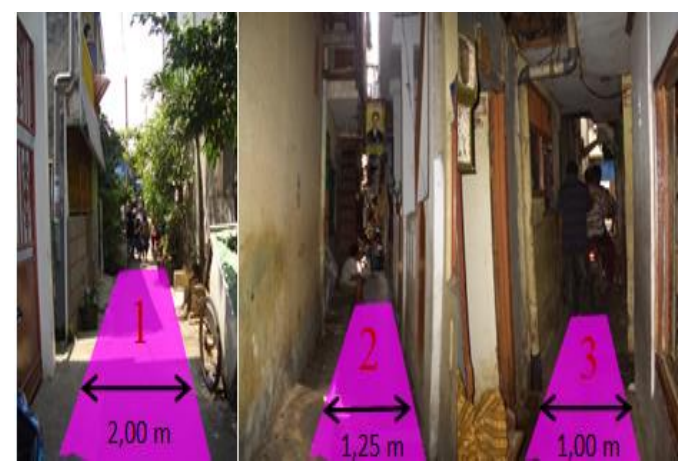

Gambar 2: Kondisi Jalan Lingkungan yang Terbentuk

Respon desain pada lokasi penelitian akan melakukan penataan kembali terhadap pola jalan. Ketentuan lebar yang memenuhi standar, untuk jalan lokal sekunder I akan ditata ulang menjadi 
Jurnal Geografi, Edukasi dan Lingkungan (JGEL) Vol. 3, No. 1, Januari 2019:45-54

P-ISSN: 2579-8499; E-ISSN: 2579-8510

DOI: https://doi.org/10.29405/jgel.v3i1.2992

Website: http://journal.uhamka.ac.id/index.php/jgel

4 meter, jalan lokal sekunder II menjadi 3 meter dan jalan lokal sekunder III menjadi 2 meter (Gambar 3).

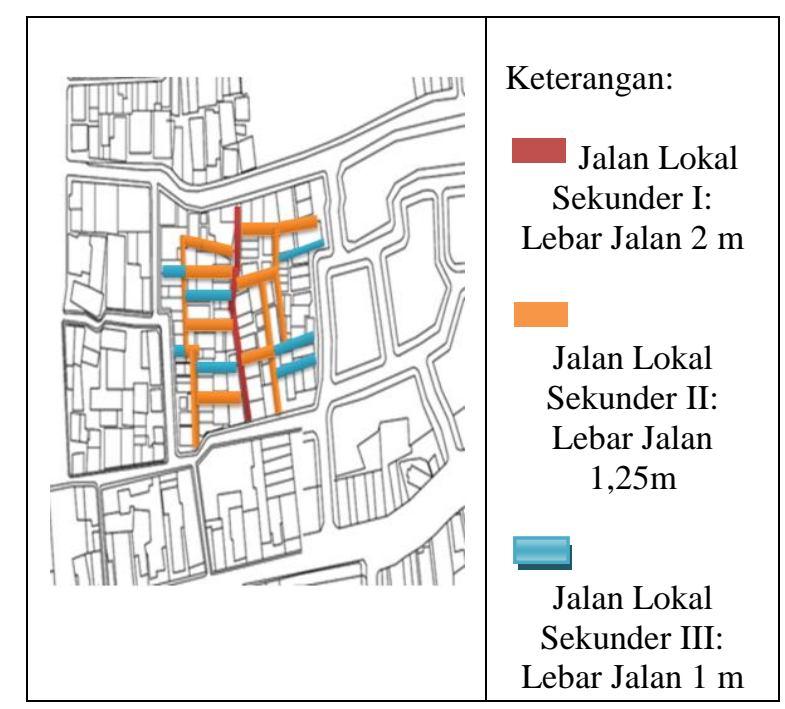

Gambar 3: Hirarki Pola Jalan Lingkungan Eksisti

Kehidupan sosial masyarakat di Desa Bojongsoang sehari-hari yang merupakan masyarakat menengah kebawah, dengan suku bangsa terbanyak adalah suku jawa, dimana suku jawa, sehingga memiliki budaya yang menjunjung tinggi nilai kebersamaan serta menjalin sosialisasi secara baik dengan para tetangga. Hal tersebut dapat dilihat dari kebiasaan masyarakat yang suka berkumpul bersosialisasi dengan para tetangga di teras rumah atau di sepanjang gang rumah mereka. Foto-foto keadaan interaksi sosial masyarakat di Kabupaten Bandung (Gambar 4).

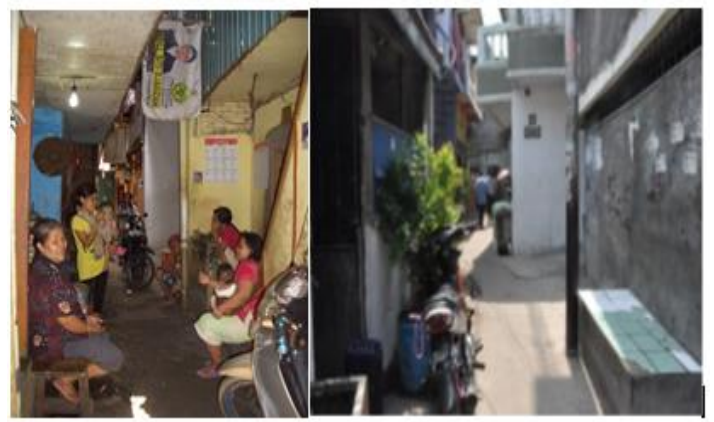

Gambar 4: Interaksi Sosial Masyarakat
Respon desain diperlukan ruang komunal untuk bersosialisasi, dan diperlukan juga teras yang cukup luas yang dapat digunakan sebagai ruang bersama (communal space) untuk menerima tamu. Untuk sanitasi, akan dianalisa keadaan fisik MCK umum. Berdasarkan pengamatan langsung, ditemukan fenomena rendahnya pengetahuan dan pemahaman masyarakat tentang pentingnya sanitasi lingkungan permukiman yang sehat. Foto-foto keadaan MCK umum di Kabupaten Bandung (Gambar 5).

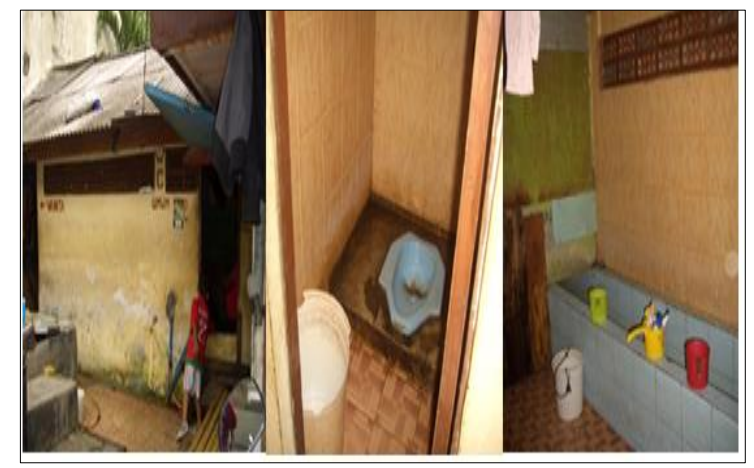

Gambar 5: MCK Umum RT 03 dan RT 05

Solusi respon desain yang baik pada lokasi penelitian adalah akan disediakan MCK dengan kualitas dan kuantitas yang lebih baik, dengan menggunakan closet jongkok dan bak mandi sesuai dengan kebiasaan warga. Sistem drainase, akan dianalisa sistem drainase dilihat dari kondisi nyata di lapangan, saluran got di jalan kampung sebagai digunakan sebagai pembuangan air kotor dan sampah-sampah. Foto-foto keadaan drainase di Kabupaten Bandung (Gambar 6). 
Jurnal Geografi, Edukasi dan Lingkungan (JGEL) Vol. 3, No. 1, Januari 2019:45-54

P-ISSN: 2579-8499; E-ISSN: 2579-8510

DOI: https://doi.org/10.29405/jgel.v3i1.2992

Website: http://journal.uhamka.ac.id/index.php/jgel

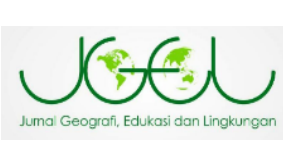

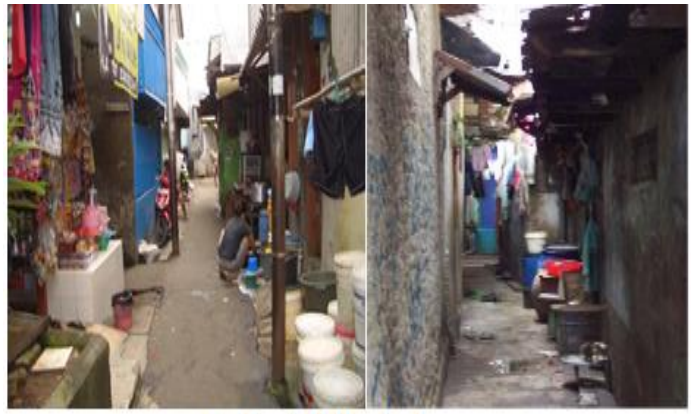

Gambar 6: Kondisi Drainase

Respon desain pada setiap unit hunian akan disediakan ruang untuk mencuci pakaian, agar warga tidak sembarangan membuang sisa deterjen cucian ke saluran got, membiasakan warga agar menjaga kebersihan saluran drainase didepan rumah. Untuk sistem persampahan, akan dianalisa kebiasaan masyarakat dalam hal membuang sampah di permukiman. Kebiasaan masyarakat membuang sampah yaitu sampah basah atau sampah kering tidak dipisahkan, sehingga menimbulkan bau tidak sedap. Respon desain harus disediakan tempat persampahan pada lingkungan permukiman ini, yaitu dengan menyediakan tempat sampah kering (orange) dan tempat sampah basah (biru)

2. Nilai kehidupan sosial ecovillage berasal dari komunitas masyarakatnya

Untuk Sarasehan, akan dianalisa kehidupan komunitas yang sudah terbentuk sejak lama di permukiman. Aktivitas sarasehan ini merupakan kegiatan sosial yang menyatukan warga, mereka tidak dibedakan oleh agama, etnis maupun kedudukan. Sarasehan dilakukan berkeliling dari rumah yang satu ke rumah yang lain secara bergiliran. Respon desain dibutuhkan balai pertemuan warga guna untuk melakukan sarasehan atau acara kegiatan lainnya.

Untuk komunitas karang taruna dan FBR, akan dianalisa kehidupan komunitas yang sudah terbentuk sejak lama di permukiman. Adanya kegiatan karang taruna dan FBR pada komunitas ini yang dilakukan berkeliling dari rumah yang satu ke rumah yang lain secara bergiliran. Solusi desain pada lokasi penelitian adalah perlu disediakan ruangan kerja dan ruang pertemuan untuk komunitas karang taruna dan FBR sebagai bentuk kegiatan bersama.

3. Masyarakat ecovillage mencari untuk mendapatkan kembali ukuran kontrol atas sumber daya mereka sendiri di dalam komunitas

Untuk air bersih, akan dianalisa kebiasaan sehari-har masyarakat dalam penggunaan air bersih. Untuk memenuhi kebutuhan air bersih warga di lingkungan permukiman ini memanfaatkan air tanah dari sumur timba.

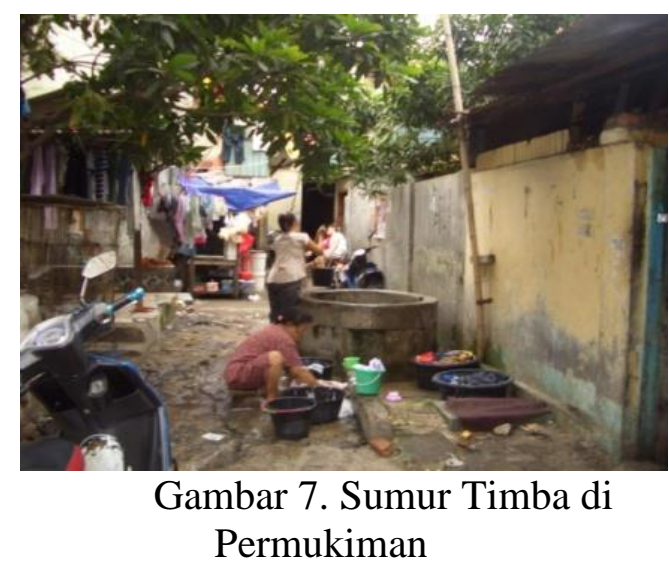

4. Masyarakat ecovillage memiliki rasa yang kuat dari nilai-nilai bersama, yang sering mereka cirikan dalam hal spiritual.

Untuk aktivitas kultural, akan dianalisa kehidupan masyarakat dalam aktivitas keagaaman yang didapatkan dari observasi dimana masyarakat memiliki kultur yang menjunjung tinggi nilai ajaran Islam. Adanya kehidupan agamis seperti pengajian, majelis dzikir dan marawis, sehingga kebiasaan ini bisa menjadi kebudayaan yang bisa di abadikan di daerah sekitar. 
Jurnal Geografi, Edukasi dan Lingkungan (JGEL) Vol. 3, No. 1, Januari 2019:45-54

P-ISSN: 2579-8499; E-ISSN: 2579-8510

DOI: https://doi.org/10.29405/jgel.v3i1.2992

Website: http://journal.uhamka.ac.id/index.php/jgel

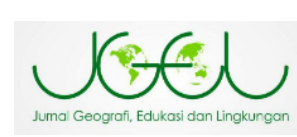

5. Ecovillage berfungsi sebagai lokasi penelitian dan sebagai lingkungan percontohan

Berdasarkan hasil pengamatan kondisi eksisting di permukiman Kabupaten Bandung, tidak tersedianya perencanaan taman di halaman rumah tinggal warga. Taman di halaman rumah ini dapat dimanfaatkan sebagai apotek hidup. Apotek hidup adalah memanfaatkan sebagian tanah untuk ditanami tanaman obat-obatan untuk keperluan sehari-hari. Tumbuhan yang dipelihara ini dapat dijadikan obat penyakit tertentu, dengan menanam tanaman obat-obatan di halaman rumah, selain dimanfaatkan untuk obat dapat juga ditata dengan baik sebagai penghias halaman rumah. Halaman rumah menjadi tampak asri dan penghuninya dapat memperoleh obat-obatan yang diperlukan untuk menjaga kesehatan.

\section{Tapak Perencanaan}

Lokasi tapak perencanaan terletak di Desa Bojongsoang, Kabupaten Bandung, dengan luas $7.550 \mathrm{~m}^{2}$. Status tanah yang berada di Jalan Tambora adalah hak milik. Umumnya, hunian untuk rumah penduduk terdiri dari 1-2 lantai. Berikut foto - foto keadaan rumah di Jalan ciapus Banjaran RT 03 dan RT 05 (Gabar 8).

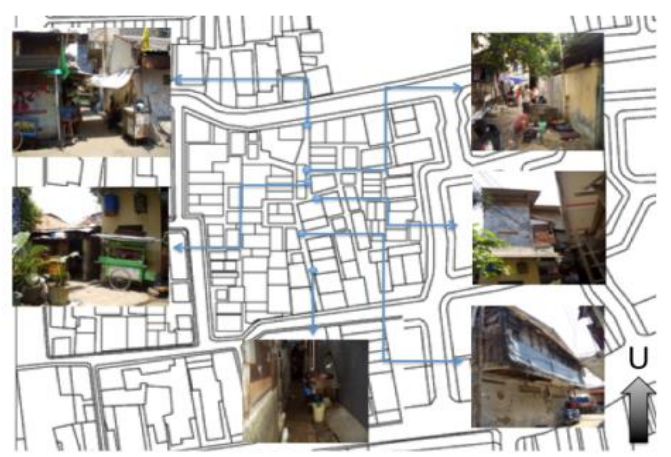

Gambar 8. Keadaan Lokasi di RT 03 dan RT 05

\section{Kebutuhan Sarana Prasarana}

Pada lokasi tapak yang merupakan permukiman kumuh memiliki batasanbatasan dengan wilayah lain atau sekitar tapak, pada sekitar tapak memiliki sarana prasarana. Maka akan didapatkan kesimpulan mengenai kebutuhan sarana pada Kabupaten Bandung Desa Bojongsoang. Keadaan dan kelengkapan sarana dan prasana yang ada akan dapat menunjang kegiatan masyarakat, maka dari itu bebrapa sarana dan prasarana minimal yang harus disiapkan serta tersedia disajikan pada Tabel 2:

Tabel 2. Kebutuhan Sarana di Desa Bojongsoan, Kabupaten Bandung

\begin{tabular}{|c|c|c|c|}
\hline \multirow{2}{*}{$\begin{array}{c}\text { No. } \\
1\end{array}$} & \multirow{2}{*}{$\begin{array}{l}\text { Kriteria di } \\
\text { Permukiman } \\
\text { TK }\end{array}$} & \multicolumn{2}{|c|}{$\begin{array}{c}\text { Fakta Lapangan } \\
\text { di Desa Bojongsoang } \\
\text { Barat }\end{array}$} \\
\hline & & 4 & $\sqrt{ }$ \\
\hline & SD & 5 & $\sqrt{ }$ \\
\hline & SLTP & 3 & $\sqrt{ }$ \\
\hline & SMU & 1 & $\sqrt{ }$ \\
\hline \multirow[t]{3}{*}{2} & & & $\sqrt{ }$ \\
\hline & Posyandu & 2 & \\
\hline & $\begin{array}{l}\text { Balai } \\
\text { pengobatan } \\
\text { Warga }\end{array}$ & 1 & $\sqrt{ }$ \\
\hline \multirow[t]{2}{*}{3} & Musholla & 3 & $x$ \\
\hline & Mesjid warga & & $\sqrt{ }$ \\
\hline \multirow[t]{4}{*}{4} & Toko/warung & $>5$ & $\sqrt{ }$ \\
\hline & $\begin{array}{l}\text { Pasar } \\
\text { lingkungan }\end{array}$ & 1 & $\sqrt{ }$ \\
\hline & $\begin{array}{l}\text { Taman/tempat } \\
\text { main }\end{array}$ & 0 & $x$ \\
\hline & $\begin{array}{l}\text { Taman dan } \\
\text { lapangan olah }\end{array}$ & 0 & $x$ \\
\hline
\end{tabular}

Sumber: Web Kecamatan Bojongsoang diakses 2017

Berdasarkan Tabel 2, terlihat bahwa tidak adanya taman atau tempat main dan lapangan olahraga. Kondisi tersebut mengakibatkan pada perancangan permukiman memerlukan fasilitas sarana tersebut. 
Jurnal Geografi, Edukasi dan Lingkungan (JGEL) Vol. 3, No. 1, Januari 2019:45-54

P-ISSN: 2579-8499; E-ISSN: 2579-8510

DOI: https://doi.org/10.29405/jgel.v3i1.2992

Website: http://journal.uhamka.ac.id/index.php/jgel

\section{KESIMPULAN}

Berdasarkan uraian fakta yang telah dianalisis diatas, dapat diketahui bahwa agar permukiman tidak menjadi bertambah padat dan kumuh solusi yang dapat ditwarkan adalah dengan cara peremajaan permukiman. Peremajaan permukiman kumuh merupakan kegiatan untuk memperbaiki dan untuk memperbaharui suatu kawasan kota yang memiliki mutu lingkungannya rendah. Tambora terletak di lokasi strategis sehingga warga tidak ingin pindah dari Tambora. Proyek peremajaan permukiman melalui penerapan konsep ecovillage dengan membangun permukiman yang berkelanjutan dan ekologis, yang menggunakan prinsip berkelanjutan dengan mengedepankan aspek lingkungan dan berintegrasi dengan dimensi sosial, ekonomi, dan budaya.

\section{DAFTAR PUSTAKA}

Aulia, D. N. (2005). Permukiman Yang

Berwawasan Lingkungan

Tinjauan. Jurnal Sistem Teknik Industri, 6, 35-39.

Dawson, J. (2007). Ecovillages: New Frontiers for Sustainability. Canada.

Jackson, H. (2005). Integrated Ecovillage Design: A New Planning Tool for Sustainable Settlements. Journal of Resources and Ecology, 1-8.

Musthofa, Z. (2011). Evaluasi Pelaksanaan Program Relokasi Permukiman Kumuh. 2(1), 137 141.

Puspita, A. A. (2013). Analisis Upaya Masyarakat Dalam Mewujudkan Kampung Hijau (Studi Kasus: Kelurahan Gayamsari, Kota Semarang). Jurnal Lingkungan, 36-40. 